\title{
Effect of different levels of phosphorus on rumen microbial fermentation and synthesis determined using a continuous culture technique
}

\author{
BY SYLVIE KOMISARCZUK*, R. J. MERRY† AND A. B. MCALLAN†‡ \\ National Institute for Research in Dairying, Shinfield, Reading, Berkshire RG2 9AT
}

(Received 22 May 1986 - Accepted 7 November 1986)

1. A continuous culture technique was used to study the phosphorus requirements of rumen micro-organisms. Solutions of artificial saliva containing $120,80,40$ and $0 \mathrm{mg}$ inorganic phosphorus $\left(\mathrm{P}_{\mathrm{i}}\right) / 1$ were infused into the reaction vessels previously inoculated with rumen contents, resulting in $P_{i}$ concentrations in the vessel contents of $48,28,4$ and $<1 \mathrm{mg} / 1$ respectively. Various fermentative and synthetic characteristics were examined.

2. In the vessel contents, concentrations of protozoa (about $0.9 \times 10^{5} / \mathrm{ml}$ ) were not significantly affected by $P_{j}$ concentration. Total volatile fatty acids (VFA) produced averaged about $6.83 \mathrm{mmol} / \mathrm{h}$ with $P_{i}$ levels of 48 and $28 \mathrm{mg} / \mathrm{l}$. Reduction in $\mathrm{P}_{1}$ concentrations to 4 and $<1 \mathrm{mg} / 1$ resulted in significant reductions in total VFA to approximately 6.25 and $3.75 \mathrm{mmol} / \mathrm{h}$ respectively, accompanied by a rise in $\mathrm{pH}$ from 6.5 to 7.3 . Ammonia-nitrogen values, which averaged about $131 \mathrm{mg} / 1$ at the higher $P_{i}$ concentrations, also increased with the lowest level of $P_{i}$ to about $240 \mathrm{mg} / 1$. ATP concentrations averaged about $14 \mu \mathrm{mol} / 1$ at the highest $P_{1}$ concentration and fell progressively with each reduction in $P_{i}$ concentration to a final value of $2.5 \mu \mathrm{mol} / 1$ with the $P_{i}$ level $<1 \mathrm{mg} / 1$.

3. At $P_{i}$ concentrations of 48 and $28 \mathrm{mg} / \mathrm{l}$, the digestibilities of xylose, arabinose and cellulose-glucose were maintained at about $0.90,0.62$ and $0.70 \mathrm{~g} / \mathrm{g}$ input respectively. At lower $P_{i}$ concentrations these digestibilities fell significantly and corresponding values at $P_{i}<1 \mathrm{mg} / 1$ were $0.73,0.41$ and 0.31 respectively. Starch digestion was unaffected by $P_{j}$ concentration and remained at about $0.90 \mathrm{~g} / \mathrm{g}$ input.

4. The amount of microbial- $N$ synthesized averaged $0.48 \mathrm{~g} / \mathrm{d}$ and was maintained with $P_{1}$ concentrations down to $4 \mathrm{mg} / 1$. There was, however, a significant reduction $100.26 \mathrm{~g} / \mathrm{d}$ with $\mathrm{P}_{\mathrm{i}}$ concentrations of $<1 \mathrm{mg} / \mathrm{l}$. The efficiency of microbial protein synthesis was variable but averaged approximately $25 \mathrm{~g} \mathrm{~N} / \mathrm{kg}$ total carbohydrate fermented.

5. It was estimated that the minimum $P_{i}$ concentrations required in rumen fluid in vivo to maintain maximum degradative and synthetic microbial activities was in the range $75-100 \mathrm{mg} / \mathrm{l}$ and that the over-all $P$ requirement of the microbes was of the order of $5 \cdot 1 \mathrm{~g} / \mathrm{kg}$ apparently digested organic matter intake.

Phosphorus deficiency is a major problem in many areas of the world. Most of the normal forages consumed by ruminants are little more than adequate with respect to their $P$ content. Furthermore, increasing use of poor-quality roughages and by-products such as sugar-beet pulp, generally deficient in $P$, tends to exacerbate the problem. It has frequently been shown that feeding P-deficient diets could lead to decreased voluntary feed intake (Preston \& Pfander, 1964; Coombe et al. 1971; Smith, 1984) with consequent effects on growth rate, milk production, etc. (Hemingway, 1967). These effects may be at least in part a result of impaired rumen function (Fishwick et al. 1977, Bass et al. 1981; Durand et al. 1982; Breves \& Holler, 1983). In general, ruminant feeds sustain the symbiotic rumen micro-organisms and only indirectly the host animal (Hungate, 1966) and it has been suggested that the $\mathbf{P}$ requirements of these organisms may be greater than that of the host animal (Preston \& Pfander, 1964). There is, however, a strong interaction between the host animal and the rumen micro-organisms with respect to $P$ supply and utilization, and in order to ascertain precise requirements of the micro-organisms, studies need to be carried out in situations which are not influenced by the host animal.

In vitro work with pure cultures of rumen bacteria have shown the essentiality of $\mathbf{P}$ for growth (Bryant et al. 1959) and its effects on growth rates and yields (Caldwell et al. 1973;

Present addresses:* Station de Recherches de Nutrition, CNRZ, Domaine de Vilvert 78350, Jouy-en-Josas, France. $†$ Animal and Grassland Research Institute, Hurley, Maidenhead, Berkshire SL6 5LR.

$\ddagger$ For reprints 
Stewart, 1975). Further work using suspensions of mixed rumen micro-organisms, frequently P-depleted, have shown the beneficial effects of additional $\mathrm{P}$ with respect to increased cellulolytic activity (Burroughs et al. 1951; Anderson et al. 1956; Hall et al. 1961; Ammerman et al. 1965; Chicco et al. 1965) and increased $\mathrm{N}$ utilization (Burroughs et al. 1951; Bonilla, 1976; Durand et al. 1983 b). These studies were made using relatively short-term batch culture techniques and only examined the effects of $P$ on one or at most two products of microbial fermentation and synthesis and it has been suggested that optimal conditions required for one aspect of microbial metabolism may not necessarily apply to other aspects (McAllan \& Smith, 1983). Recently, using a semi-continuous culture technique, a more detailed examination of the effects of $P$ repletion on different aspects of microbial activity confirmed the importance of $P$ in fibre digestion (Durand et al. 1986).

Using a continuous-culture rumen simulation technique, the present studies were undertaken to examine simultaneously a number of characteristics associated with degradative and synthetic processes in the rumen in order to ascertain more precisely the minimum $P$ requirements for these processes.

Preliminary reports on parts of this work have been published elsewhere (Komisarczuk et al. 1984b, 1985, 1986).

\section{MATERIALS AND METHODS \\ Inoculum source}

Three Suffolk $\times$ Blackface wether sheep $(60-70 \mathrm{~kg})$, each equipped with simple rumen cannulas (Smith \& McAllan, 1970), were used to provide fresh rumen contents. The animals were given diets consisting of chopped barley straw (0.49), dried sugar-beet pulp $(0.29)$, tapioca $(0 \cdot 20)$ and urea $(0 \cdot 02)$. The proportional contribution of each constituent to the total diet is given in parentheses. The diet was given at a level of $1.1 \mathrm{~kg}$ fresh weight $/ \mathrm{d}$ in two equal portions at 09.00 and 17.00 hours and supplied $15.1 \mathrm{~g} \mathrm{~N}$ and $9.4 \mathrm{MJ}$ metabolizable energy (ME)/d which was calculated to be sufficient for maintenance requirements (Agricultural Research Council, 1980). Samples (approximately 1.5 litres) of rumen digesta as required were taken from each sheep immediately before the morning feed, combined, mixed and strained through four layers of surgical gauze. The pooled, strained sample was used to charge the fermentation vessels within $30 \mathrm{~min}$ of collection.

\section{Equipment and diets}

The continuous-culture equipment used was that developed by Hoover et al. (1976) as modified by Merry et al. (1987). This system enables independent manipulation of both solid and liquid outflow rates by means of a dual effluent system. A portion of the effluent is pumped from the vessel continuously at a predetermined rate through a filter (filtered effluent, $F_{e}$ ) and the remainder leaves the vessel by means of displacement (displaced effluent, $D_{e}$ ). To prepare a sample representative of the total daily effluent (mixed effluent, $M_{e}$ ), portions of $F_{e}$ and $D_{e}$ were combined in proportions related to individual daily outflows.

Both culture vessels received $40 \mathrm{~g}$ fresh weight/d of a diet of identical composition to that given to the donor animals. The constituents were individually ground to pass through a $5 \mathrm{~mm}$ screen and pelleted together. The pellets were approximately $2.5 \mathrm{~mm}$ in diameter and not more than $8 \mathrm{~mm}$ in length. The diet was delivered continuously by automatic feeder (Merry et al. 1987) and its chemical composition is shown in Table 1 together with daily inputs of dietary constituents. Artificial saliva (a 60:40 aqueous dilution of the artificial saliva described by McDougall, 1948) was infused continuously at a rate of $70 \mathrm{ml} / \mathrm{h}$ and $F_{e}$ was removed at a rate of $31 \mathrm{ml} / \mathrm{h}$. 
Table 1. Diet composition $(\mathrm{g} / \mathrm{kg}$ fresh weight) and daily inputs $(\mathrm{g} / \mathrm{d})$ of dietary constituents to continuous culture vessels

\begin{tabular}{llc}
\hline Constituent & $\begin{array}{c}\text { Diet content } \\
(\mathrm{g} / \mathrm{kg} \text { fresh weight })\end{array}$ & $\begin{array}{c}\text { Input to vessels } \\
(\mathrm{g} / \mathrm{d})\end{array}$ \\
\hline Dry matter & 910 & 36.4 \\
Organic matter & 850 & 34.0 \\
Cellulose & 251 & $10 \cdot 1$ \\
Hemicellulose* & 181 & 7.23 \\
Arabinose & 82.2 & 3.29 \\
Xylose & 98.5 & 3.94 \\
Starch & 161 & 6.47 \\
Total nitrogen & 24 & 0.96 \\
Amino-N & 10 & 0.40 \\
Urea-N & 14 & 0.56 \\
Total phosphorus & 0.64 & 0.025 \\
\hline
\end{tabular}

* Sum of arabinose $+x y l o s e$.

\section{Experimental protocol, preliminary experiment}

In order to reduce the range of inorganic $P\left(P_{i}\right)$ concentrations to be examined, a single preliminary experiment was carried out. The over-all protocol of this experiment is as described later for the main experiments. Two culture vessels were charged with rumen contents containing approximately $500 \mathrm{mg} \mathrm{P}_{\mathrm{i}} / 1$. The control vessel was infused with artificial saliva containing $480 \mathrm{mg} P_{j} / 1$ (resulting in a vessel content of $411 \mathrm{mg} P_{i} / 1$ ) throughout the experiment. The experimental vessel was consecutively infused with artificial saliva containing $480,250,100$ and $0 \mathrm{mg} \mathrm{P} / 1$, which resulted in vessel concentrations of approximately $411,185,54$ and $2 \mathrm{mg} P_{i} / 1$ respectively. No significant effects were observed on $\mathrm{pH}$, total volatile fatty acids VFA production, molar proportions of $\mathrm{VFA}, \mathrm{NH}_{3}$ levels or ATP concentrations with $P_{i}$ vessel levels of 411,185 or $54 \mathrm{mg} / 1$ compared with the control vessel. There were considerable differences between vessels for all measurements made when the experimental vessel had no $P_{i}$ infused. It was therefore decided to concentrate our study on vessel $P_{i}$ levels of approximately $50 \mathrm{mg} / \mathrm{l}$ and less, corresponding to a salivary supply of $120 \mathrm{mg} / 1$ or less.

\section{Experimental protocol, main experiments}

Each run of the experiment lasted for $22 \mathrm{~d}$ and was divided into four periods. Period 1 lasted $7 \mathrm{~d}$ and periods 2, 3 and 4 for $5 \mathrm{~d}$ each. Each vessel was charged with approximately 1 litre rumen contents. The control vessel was infused continuously with artificial saliva containing $120 \mathrm{mg} \mathrm{P} / 1$ (resulting in a vessel $P_{j}$ concentration of $51 \mathrm{mg} / \mathrm{l}$ ) over the whole experimental period of $22 \mathrm{~d}$. The experimental vessel was infused with artificial saliva containing ( $\left.\mathrm{mg} \mathrm{P}_{\mathrm{i}} / \mathrm{l}\right) 120$ (period 1), 80 (period 2), 40 (period 3) and 0 (period 4) which resulted in vessel $P_{i}$ concentrations $(\mathrm{mg} / \mathrm{l})$ of approximately $48,28,4$ and $<1$ respectively (Fig. 1). Thiamin $(200 \mathrm{mg} / \mathrm{l})$ and cysteine monohydrochloride $(25 \mathrm{mg} / \mathrm{l})$ were included in the artificial saliva. Reductions in the buffering capacity by elimination of $\mathrm{Na}_{2} \mathrm{HPO}_{4}$ were balanced by replacement with $\mathrm{Na}_{2} \mathrm{HCO}_{3}$ (Table 2). Each period consisted of equilibration for $2 \mathrm{~d}$ (except for period 1 where equilibration for $5 \mathrm{~d}$ was allowed) followed by daily sampling over the next $3 \mathrm{~d}$. These periods were found to be adequate in the present system (Merry et al. 1987). Samples of filtered vessel contents and $M_{e}\left(F_{f}+D_{e}\right)$ were taken as described by Merry et al. (1987). Protozoal numbers, $\mathrm{pH}, \mathrm{P}_{\mathrm{i}}$ and ATP concentrations were 


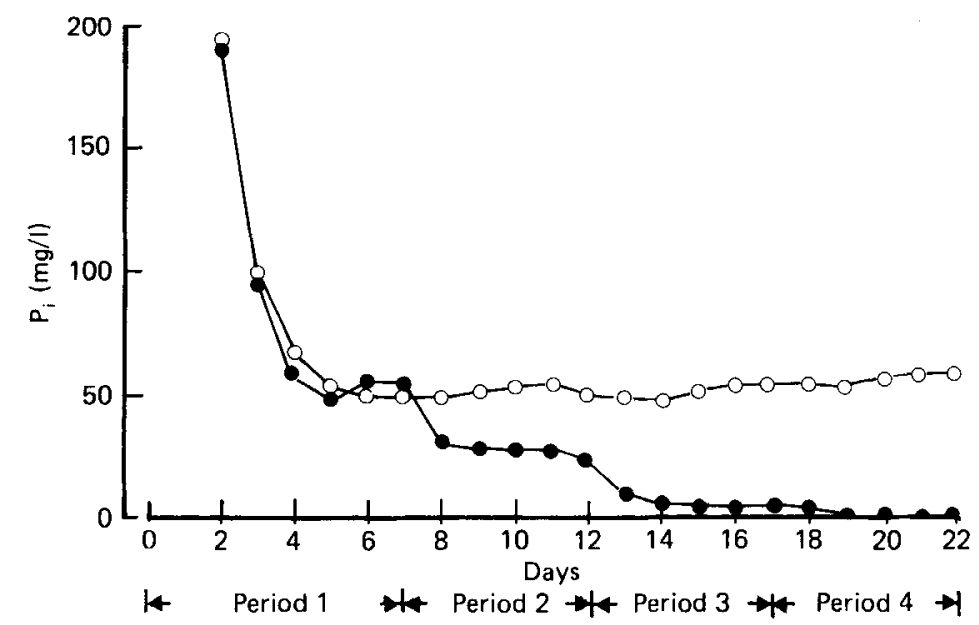

Fig. 1 Daily inorganic phosphorus $\left(P_{i}\right)$ concentrations in continuous culture media being infused with buffer solution containing $120 \mathrm{mg} \mathrm{P}_{\mathrm{i}} / \mathrm{l}$ over the total four experimental periods $(O$; control vessel) and those being infused with buffer solutions containing 120 (period 1), $80($ period 2), 40 (period 3) and 0 (period 4) $\mathrm{mg} \mathrm{P}_{\mathrm{i}} / \mathrm{l}$ ( ; experimental vessel).

measured in sub-samples of filtered vessel contents after the necessary preliminary treatments. Similarly VFA, carbohydrates, $\mathrm{NH}_{3}-\mathrm{N}$ and total microbial-N contents were estimated in each $\mathbf{M}_{\mathrm{e}}$ sample. Samples of mixed rumen bacteria were harvested once during each period by the method of Smith \& McAllan (1974). A sub-sample of the mixed bacteria was analysed immediately for RNA content and the remainder stored at $-20^{\circ}$ to await further analysis.

Experiments were replicated four times, each with fresh inoculum, with the control and experimental treatments alternating between vessels.

\section{Analytical}

RNA was determined according to the procedure of McAllan \& Smith (1969) and values were used to estimate microbial-N flow as described by McAllan \& Smith (1983). Total-N was determined by the procedure of Smith \& McAllan (1970) and carbohydrates by the method of McAllan \& Smith (1974). Dry matter (DM), ash and $P_{i}$ contents were estimated as described by Smith $e$ t al. (1978) and total-P by the method of McAllan \& Smith (1977). $\mathrm{NH}_{3}-\mathrm{N}$ concentrations and protozoal numbers were determined as described by Merry et al. (1987) and ATP by the procedure of Komisarczuk et al. (1984a). The amounts of organic matter (OM) fermented were calculated from the amounts of VFA produced using the formula proposed by Van Nevel \& Demeyer (1977).

\section{Statistical analysis}

Analysis of variance (Snedecor \& Cochran, 1972) was used to determine the significance of difference between control and $\mathbf{P}_{i}$ levels within each period by the least significant difference (LSD) where $\alpha=0.05$. Replicates were used as a blocking factor, all other effects were pooled to give 21 degrees of freedom. The chemical composition of bacteria was analysed using a paired $t$ test (Snedecor \& Cochran, 1972). 
Table 2. The compositions $(\mathrm{g} / \mathrm{l})$ of artificial salivas infused in the control vessels throughout the experiment and the experimental vessels for period $I(A)$ and in the experimental vessels for periods $2(B), 3(C)$ and $4(D)$. Also shown are the inorganic phosphorus $\left(P_{i}\right)$ concentrations ( $\mathrm{mg} / \mathrm{l}$ ) of the salivas. All salivas were at $\mathrm{pH} 9 \cdot 0$

\begin{tabular}{|c|c|c|c|c|}
\hline $\begin{array}{l}\text { Period ... } \\
\text { Saliva ... }\end{array}$ & $\begin{array}{l}1 \\
\mathrm{~A}\end{array}$ & $\begin{array}{l}2 \\
\mathrm{~B}\end{array}$ & $\begin{array}{l}3 \\
\mathrm{C}\end{array}$ & $\begin{array}{l}4 \\
D\end{array}$ \\
\hline $\begin{array}{l}\mathrm{NaHCO}_{3} \\
\mathrm{Na}_{2} \mathrm{HPO}_{4} \cdot 12 \mathrm{H}_{2} \mathrm{O} \\
\mathrm{NaCl} \\
\mathrm{KCl} \\
\mathrm{MgCl} \\
\mathrm{P}_{\mathrm{i}}\end{array}$ & $\begin{array}{c}7.56 \\
1.38 \\
0.45 \\
0.35 \\
0.077 \\
120\end{array}$ & $\begin{array}{l}7.65 \\
0.92 \\
0.49 \\
0.35 \\
0.077 \\
80\end{array}$ & $\begin{array}{l}7 \cdot 76 \\
0 \cdot 46 \\
0 \cdot 61 \\
0 \cdot 35 \\
0.077 \\
40\end{array}$ & $\begin{array}{l}7 \cdot 81 \\
0 \cdot 00 \\
0.66 \\
0 \cdot 35 \\
0 \cdot 077 \\
0\end{array}$ \\
\hline
\end{tabular}

Thiamin $(200 \mathrm{mg} / \mathrm{l})$ and cysteine monohydrochloride $(25 \mathrm{mg} / \mathrm{l})$ were aiso included.
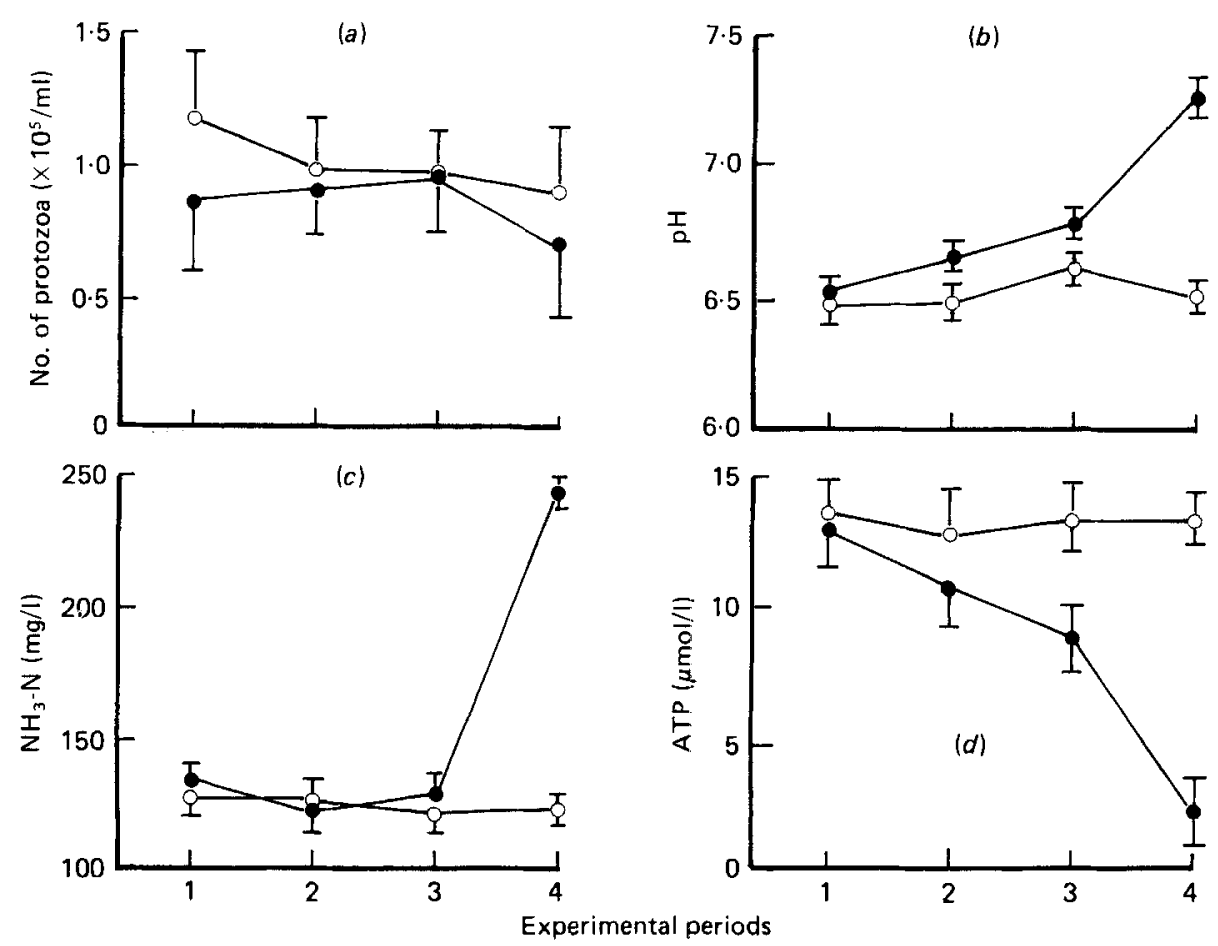

Fig. 2 (a) Numbers of protozoa, (b) pH values, $(c)$ ammonia-nitrogen and $(d)$ ATP concentrations in continuous culture media infused with solutions containing $120 \mathrm{mg}$ inorganic phosphorus $\left(P_{i}\right) / 1$ over the total four experimental periods $(O$; control vessel) and those being infused with solutions containing 120 (period 1), 80 (period 2), 40 (period 3) and 0 (period 4) $\mathrm{mg} \mathrm{P}_{\mathrm{i}} / \mathrm{l}$ (O) experimental vessel). Results are mean values for four experiments in each period, each experimental value being the mean of three separate daily collections. The vertical bars represent the least significant differences.

\section{RESULTS}

Effects of $P_{i}$ concentration on protozoal numbers, $\mathrm{pH}, \mathrm{NH}_{3}$ and $\mathrm{ATP}$ concentrations The numbers of protozoa found in the liquid phase of culture-vessel contents are presented in Fig. 2(a). In the control vessels there was a fall in numbers from period 1 to period 2 but these values then stabilized at about $1 \times 10^{5}$ counts $/ \mathrm{ml}$. Numbers in the experimental 
Table 3. The effects of inorganic phosphorus $\left(P_{i}\right)$ concentration on total volatile fatty acids (VFA) production ( $\mathrm{mmol} / \mathrm{d})$, molar proportions of individual VFA (mol VFA/mol total VFA) and the amount $(\mathrm{g} / \mathrm{d})$ of organic matter and total carbohydrate fermented in continuous culture vessels

(For the sake of clarity results for the control vessels are presented as overall mean values for four experimental periods, each period value being the mean of four experiments and each experimental value being the mean of three separate daily collections (forty eight samples). Results for the experimental vessels are presented as means for four experiments in each period, each experimental value being the mean of three separate daily collections)

\begin{tabular}{|c|c|c|c|c|c|c|c|c|}
\hline \multirow[b]{2}{*}{ Vessel } & \multirow[b]{2}{*}{ Period } & \multirow{2}{*}{$\begin{array}{l}P_{i} \text { in } \\
\text { vessel } \\
(\mathrm{mg} / \mathrm{l})\end{array}$} & \multirow{2}{*}{$\begin{array}{c}\text { Total } \\
\text { VFA } \\
(\mathrm{mmol} / \mathrm{d})\end{array}$} & \multicolumn{3}{|c|}{ Molar proportion } & \multirow{2}{*}{$\underset{(\mathrm{g} / \mathrm{d})}{\mathrm{OMF} \dagger}$} & \multirow{2}{*}{$\begin{array}{c}\mathrm{TCF} \\
(\mathrm{g} / \mathrm{d})\end{array}$} \\
\hline & & & & Acetate & Propionate & Butyrate & & \\
\hline Control & $1-4$ & 51 & $173 \cdot 0$ & 0.731 & 0.151 & 0.092 & $15 \cdot 2$ & $18 \cdot 3$ \\
\hline \multirow[t]{4}{*}{ Experimental } & 1 & 48 & $163 \cdot 1$ & 0.730 & $0 \cdot 158$ & 0.090 & $13 \cdot 9$ & $18 \cdot 6$ \\
\hline & 2 & 28 & 164.4 & 0.732 & $0 \cdot 157$ & 0.079 & $14 \cdot 2$ & $18 \cdot 4$ \\
\hline & 3 & 4 & $149 \cdot 3 *$ & 0.716 & $0 \cdot 162$ & $0 \cdot 082$ & $12 \cdot 9^{*}$ & $16 \cdot 9$ \\
\hline & 4 & $<1$ & $90 \cdot 8^{*}$ & 0.679 & $0 \cdot 210^{*}$ & $0 \cdot 104$ & $8 \cdot 1^{*}$ & $12 \cdot 8^{*}$ \\
\hline LSD at $5 \%$ & - & - & $16 \cdot 3$ & 0.038 & 0.036 & 0.022 & $1 \cdot 4$ & 1.6 \\
\hline
\end{tabular}

OMF, organic matter fermented, TCF, total carbohydrate fermented; LSD, least significant difference. Significantly different from corresponding control period values: $* P \leqslant 0 \cdot 05$.

$\uparrow$ Calculated from VFA data.

vessels tended to be slightly lower than those in the control vessels but none of the differences was significant. Concentrations of $\mathrm{NH}_{3}-\mathrm{N}$ of approximately $131 \mathrm{mg} / \mathrm{l}$ were found throughout the experiment within the control vessels and in the experimental vessels with $\mathrm{P}_{\mathrm{i}}$ concentrations down to $4 \mathrm{mg} / \mathrm{l}$ (periods 1-3) (Fig. 2(c)). There was however, a significant rise $(P \leqslant 0.05)$ in $\mathrm{NH}_{3}-\mathrm{N}$ concentration to about $240 \mathrm{mg} / \mathrm{l}$ in period 4 when the experimental $\mathrm{P}_{\mathrm{i}}$ concentration was $<1 \mathrm{mg} / \mathrm{l}$. ATP levels (Fig. 2(d)) in the control vessels were constant throughout at about $14 \mu \mathrm{mol} / \mathrm{l}$. Those in the experimental vessels fell progressively with each reduction in $\mathrm{P}_{\mathrm{i}}$ concentration and were significantly different from the controls $(P \leqslant 0.05)$ in period 4 at about $2.5 \mu \mathrm{mol} / 1$.

\section{Effects of $P_{i}$ concentration on VFA production and molar proportions}

Results for both experimental and control vessels are presented in Table 3. Total VFA produced and the molar proportions of the individual VFA were constant in the control vessel throughout the experiment. In the experimental vessels, when $P_{i}$ concentrations were 48 and $28 \mathrm{mg} / 1$ (periods 1 and 2) the corresponding values for the total VFA concentrations and molar proportions of the individual VFA were very similar to those found in the control vessels. When $P_{i}$ concentrations in the experimental vessel were reduced to $4 \mathrm{mg} / 1$ (period 3 ), there were significant reductions $(P \leqslant 0.05)$ in the amounts of total VFA produced, but no significant effects were seen on the molar proportions of the VFA. Further reduction of $P_{i}$ concentration to $<1 \mathrm{mg} / 1$ (period 4) resulted in further reductions in the amounts of total VFA produced. There were also changes in the molar proportions of the individual VFA and propionate increased significantly. Increased butyrate and decreased acetate proportions were also observed, both of which approached significance at the $5 \%$ level.

\section{Effects of $P_{i}$ concentrations on carbohydrate digestion}

Daily amounts of the monosaccharide components of starch and structural carbohydrates digested in the culture vessels are presented in Table 4 . These were constant in the control 
Table 4. The effects of inorganic phosphorus $\left(P_{i}\right)$ concentration on dietary carbohydrate digestibilities ( $g$ digested/g input) in continuous culture vessels

(For the sake of clarity, results for the control vessels are presented as overall mean values for the four experimental periods, each period value being the mean of four experiments and each experimental value being the mean of three separate daily collections. Results for the experimental vessels are presented as mean values for four experiments in each period, each experimental value being the mean of three separate daily collections)

\begin{tabular}{|c|c|c|c|c|c|c|}
\hline Vessel & Period & $\begin{array}{c}P_{i} \text { in } \\
\text { vessel } \\
(\mathrm{mg} / \mathrm{l})\end{array}$ & Arabinose & Xylose & $\begin{array}{l}\text { Cellulose- } \\
\text { glucose }\end{array}$ & $\begin{array}{l}\text { Starch- } \\
\text { glucose }\end{array}$ \\
\hline Control & $1-4$ & 51 & 0.89 & 0.65 & 0.68 & 0.92 \\
\hline Experimental & $\begin{array}{l}1 \\
2 \\
3 \\
4\end{array}$ & $\begin{array}{r}48 \\
28 \\
4 \\
<1\end{array}$ & $\begin{array}{l}0.90 \\
0.91 \\
0.87 \\
0.73^{*}\end{array}$ & $\begin{array}{l}0.63 \\
0.60 \\
0.54 \\
0.41^{*}\end{array}$ & $\begin{array}{l}0.71 \\
0.69 \\
0.59^{*} \\
0.31^{*}\end{array}$ & $\begin{array}{l}0.91 \\
0.94 \\
0.91 \\
0.88\end{array}$ \\
\hline LSD at $5 \%$ & - & $\ldots$ & 0.03 & $0 \cdot 10$ & 0.08 & 0.04 \\
\hline
\end{tabular}

LSD, least significant difference.

Significantly different from corresponding control period values: ${ }^{*} P \leqslant 0.05$.

vessels over the whole experiment and represented digestibilities ( $\mathrm{g}$ digested/g input) of $0.89,0.65,0.68$ and 0.92 for arabinose, xylose, cellulose-glucose and starch-glucose respectively. Similar amounts of dietary carbohydrates were removed in experimental vessels containing 48 and $28 \mathrm{mg} \mathrm{P}_{\mathrm{i}} / 1$ (periods 1 and 2). However, digestibilities of arabinose, xylose and cellulose-glucose decreased with $P_{i}$ concentrations of $4 \mathrm{mg} / 1$ (period 3) and a further reduction in $P_{i}$ concentration to $<1 \mathrm{mg} / \mathrm{l}$ (period 4) resulted in further decreases in the digestibilities of the fibre component-sugars, which were all significant. The amounts of starch-glucose digested were not significantly affected even at the lowest concentration of $P_{i}$.

Throughout the experiment there were marked differences between the total amounts of carbohydrate fermented (which probably contributed about $80 \%$ of OM fermented) and amounts of OM fermented calculated from VFA production. Similar discrepancies have been observed and discussed by other workers (see Sutton, 1979) but reasons remain unclear.

\section{Effects of $P_{\mathrm{i}}$ concentration on microbial- $N$ flow, microbial- $N$ yield and the chemical composition of bacteria}

Total microbial-N flow values are presented in Table 5 and averaged $0.49 \mathrm{~g} / \mathrm{d}$ over the four periods in the control vessel. A similar average value $(0.48 \mathrm{~g} / \mathrm{d})$ was found over the first three periods with the experimental vessels containing 48,28 and $4 \mathrm{mg} \mathrm{P}_{\mathrm{i}} / 1$. In period 4 , however, microbial-N flow was significantly reduced to about one-half of that obtained in the control vessels. There was no evidence that the efficiency of microbial protein synthesis was affected by $P_{i}$ concentration.

The compositions of some components of the mixed bacteria isolated during the experiment are given in Table 6 . In bacteria isolated from control vessels, OM content remained constant throughout at about $900 \mathrm{~g} / \mathrm{kg}$ DM. Similar values were found in bacteria isolated from the experimental vessels over the first three experimental periods but values fell to about $750 \mathrm{~g} / \mathrm{kg} \mathrm{DM}$ in period $4\left(<1 \mathrm{mg} \mathrm{P}_{\mathrm{i}} / \mathrm{l}\right)$. Total-N and total-P concentrations, when expressed as $\mathrm{g} / \mathrm{kg} \mathrm{OM}$, were constant throughout the experiment in the control vessel 
Table 5. The effects of inorganic phosphorus $\left(P_{i}\right)$ concentration on microbial-nitrogen $(M N)$ flows $(\mathrm{g} / \mathrm{d})$ and microbial yields $(\mathrm{g} \mathrm{N} / \mathrm{kg}$ organic matter fermented $(\mathrm{OMF})$ and $\mathrm{kg}$ total carbohydrate fermented $(T C F)$ ) in continuous culture vessels

(For the sake of clarity, results for the control vessels are presented as over-all mean values for four periods, each period value being the mean of four experiments and each experimental value being the mean of three separate daily collections)

\begin{tabular}{|c|c|c|c|c|c|}
\hline \multirow[b]{2}{*}{ Vessel } & \multirow[b]{2}{*}{ Period } & \multirow{2}{*}{$\begin{array}{c}P_{i} \text { in } \\
\text { vessel } \\
(\mathrm{mg} / \mathrm{l})\end{array}$} & \multirow{2}{*}{$\begin{array}{l}\mathrm{MN} \\
\text { flow } \\
(\mathrm{g} / \mathrm{d})\end{array}$} & \multicolumn{2}{|c|}{ MN yield } \\
\hline & & & & $\mathrm{gN} / \mathrm{kg} \mathrm{OMF} \dagger$ & $\mathrm{gN} / \mathrm{kg} \mathrm{TCF}$ \\
\hline Control & $1-4$ & 51 & $0 \cdot 485$ & $31 \cdot 9$ & $26 \cdot 5$ \\
\hline \multirow[t]{4}{*}{ Experimental } & 1 & 48 & 0.437 & $31 \cdot 4$ & $23 \cdot 5$ \\
\hline & 2 & 28 & $0-478$ & $33 \cdot 7$ & 26.0 \\
\hline & 3 & 4 & 0.519 & $40 \cdot 2$ & $30 \cdot 7$ \\
\hline & 4 & $<1$ & $0.261^{*}$ & $32 \cdot 2$ & $20 \cdot 4$ \\
\hline LSD at $5 \%$ & - & - & 0.09 & $8 \cdot 0$ & 0.72 \\
\hline
\end{tabular}

LSD, least significance difference.

* Significantly different from corresponding control period value: * $P \leqslant 0.05$.

$\uparrow$ Calculated from volatile fatty acids data.

Table 6. The effects of inorganic phosphorus $\left(P_{i}\right)$ concentration on the total-nitrogen $(T N)$, total-P $(T P)$ and $R N A$ contents $(\mathrm{g} / \mathrm{kg} O M)$ of mixed bacteria isolated from continuous culture vessels. Also shown are derived $N: T P$ values

(For the sake of clarity results for the control vessel are presented as over-all mean values for four experimental periods, each period value being the mean of four experiments. Results for the experimental vessels are presented as mean values for four experiments in each period)

\begin{tabular}{|c|c|c|c|c|c|c|}
\hline \multirow[b]{2}{*}{ Vessel } & \multirow[b]{2}{*}{ Period } & \multirow{2}{*}{$\begin{array}{c}\mathrm{Pi} \text { in } \\
\text { vessel } \\
(\mathrm{mg} / \mathrm{l})\end{array}$} & \multicolumn{4}{|c|}{$\mathrm{g} / \mathrm{kg} \mathrm{OM}$} \\
\hline & & & $\begin{array}{c}\mathrm{TN} \\
\text { mean }\end{array}$ & $\begin{array}{c}\mathrm{TP} \\
\text { mean }\end{array}$ & $\begin{array}{l}N: T P \\
\text { mean }\end{array}$ & $\begin{array}{l}\text { RNA } \\
\text { mean }\end{array}$ \\
\hline Control & $1-4$ & 51 & 85.4 & $14 \cdot 7$ & 5.89 & $58 \cdot 6$ \\
\hline Experimental & $\begin{array}{l}1 \\
2 \\
3 \\
4\end{array}$ & $\begin{array}{r}48 \\
28 \\
4 \\
<1\end{array}$ & $\begin{array}{l}84 \cdot 1 \\
80 \cdot 9 \\
81 \cdot 7 \\
61 \cdot 5^{*}\end{array}$ & $\begin{array}{l}14 \cdot 3 \\
12 \cdot 3 \\
12 \cdot 7 \\
8 \cdot 0^{* * *}\end{array}$ & $\begin{array}{l}5 \cdot 84 \\
6 \cdot 54 \\
6 \cdot 44^{*} \\
7 \cdot 95\end{array}$ & $\begin{array}{l}65 \cdot 1 \\
57 \cdot 7 \\
51 \cdot 6 \\
36 \cdot 2^{\text {** }}\end{array}$ \\
\hline SEM & & & $4 \cdot 64$ & 0.54 & 0.434 & $5 \cdot 36$ \\
\hline
\end{tabular}

Significantly different from corresponding control period values (paired $t$ test): $\quad * P \leqslant 0.05, \quad * * P<0.01$, *** $P<0.001$.

with mean values of 85.4 and 14.7 respectively. RNA concentrations $(\mathrm{g} / \mathrm{kg} \mathrm{OM})$ in the control vessels were more variable with a high value (70.9) in period 1 and a low value $(47 \cdot 8)$ in period 3 , giving an over-all mean of 58.6. Total- $N$ and total-P contents in the experimental vessels over the first three experimental periods were similar to the average values found in the control vessels, but in period 4 fell significantly. Derived N:P values in the control vessels averaged $5 \cdot 89$. The corresponding value of the experimental vessels was very similar in period $1(5.84)$ but subsequently increased over the next three periods. RNA contents followed the same pattern as total-N. 
Changes in the chemical composition of the isolated bacteria may be indicative of changes in the bacterial population (Merry \& McAllan, 1983).

\section{DISCUSSION}

In the present experiments, the value of continuous culture rumen simulation, allowing simultaneous studies of a wide variety of metabolic processes over an extended period of time, has been shown. It is apparent from the present results that all the microbial processes studied were maintained at apparently normal levels with $P_{i}$ concentrations of approximately $30-50 \mathrm{mg} / 1$. This concentration was similar to published rumen microbial requirements of 20-80 mg/1 (Anderson et al. 1956; Ammerman et al. 1965; Bryant et al. 1959; Hall et al. 1961; Durand \& Kawashima, 1980; Durant et al. 1983a; Milton \& Ternouth, 1984), derived from batch-culture experiments in which the values cited were the concentrations of $P_{i}$ in the medium at the start of the experiment and therefore may only have been adequate for short-term experiments. Our values, on the other hand, were obtained when the medium was in equilibrium with microbial requirements and are probably more comparable to in vivo situations. However, marked changes in metabolic activities were observed with $P_{i}$ concentrations of about $4 \mathrm{mg} / 1$ or less. Amounts of total VFA produced were markedly reduced, contributing in part to increased $\mathrm{pH}$ values and there were indications of changes in the pattern of fermentation with reduced acetic acid and increased propionic acid production. This change in fermentative activity was confirmed by significant reductions in cellulose and hemicellulose digestion with no apparent depression of starch digestion, indicating perhaps a change in the balance of the bacterial population (Latham et al. 1974; Leedle \& Hespell, 1984). Bryant et al. (1959) have suggested a minimum requirement of $20 \mathrm{mg} P_{i} / 1$ for the maximum cellulolytic activity of pure cultures of cellulolytic bacteria, and extreme sensitivity of cellulolytic bacteria to $P$ deficiency has been reported by Durand et al. (1986). It has also been shown that cellulases isolated from mixed rumen bacteria associated with fibre have specific $P$ requirements and that the enzymes show different affinities for different fibre fractions (Francis et al. 1978). It appears that the amylolytic bacteria (or amylases) present in our system may have had lower $P$ requirements than the cellulytic or hemicellulolytic bacteria or corresponding enzymes present.

The increase in $\mathrm{NH}_{3}$ concentration observed with the lowest $\mathrm{P}_{\mathrm{i}}$ concentration indicated continuing ureolytic or proteolytic activity, or both, at greater rates than the end-products could be utilized. If one assumes that the daily outflow of total- $\mathrm{N}$ minus $\left(\mathrm{NH}_{3}-\mathrm{N}\right.$ plus microbial-N) represents the daily flow of undegraded dietary $\mathrm{N}$, it can be calculated that undegraded dietary $\mathrm{N}$ outflows in the control vessels, and experimental vessels in period 4 , were 264 and $282 \mathrm{mg} / \mathrm{d}$ respectively. These values are not significantly different which suggests that proteolytic or ureolytic activity, or both, was not affected by $\mathrm{P}_{\mathrm{i}}$ depletion.

ATP is essential for metabolic activity and contains about $180 \mathrm{~g} \mathrm{P} / \mathrm{kg}$. It was the first measured index most affected by $\mathrm{P}$ depletion. ATP is a transient entity which is difficult to measure accurately. Differences observed in vivo in ATP concentrations have been attributed to changes in numbers of protozoa (Wallace \& West, 1982; Nuzback et al. 1983). However, protozoal numbers in the liquid phase of the vessel contents in our experiments did not vary significantly throughout and it seems unlikely that the relatively small apparent drop in numbers during period 4 could account for the large (almost $90 \%$ ) reduction in ATP concentration.

It appeared that protein synthesis could be maintained with reduced ATP concentrations (period 3) and it is possible that $P$ from ATP might contribute to the maintenance of nucleic 


\section{Sylvie Komisarczuk, R. J. Merry and A. B. MCAllan}

acid synthesis which accounts for about $80 \%$ of the cellular $\mathrm{P}$ requirements (Van Nevel \& Demeyer, 1977). Indeed it has been found with species of non-rumen bacteria that an ATP nuclease can be activated in circumstances of $\mathbf{P}$ deficiency and the ribose phosphate produced used for nucleic acid synthesis (Chapman \& Atkinson, 1977). Other adaptive mechanisms contributing to $P$ salvage in order to maintain nucleic acid synthesis have also been reported (Barsdate et al. 1974). Reduced microbial-N flow at the duodenum of lambs and sheep receiving P-depleted diets has been reported (Breves et al. 1985; Durand et al. $1983 \mathrm{~b}$ ) but the effect of $\mathrm{P}$ depletion on growth yield is uncertain, having been variously reported as having no or a reducing effect (Durand et al. 1983b; Durand et al. 1986). In the present work, although there was a reduction in microbial growth at low $P_{i}$ concentrations, no evidence of reduced efficiency of microbial protein synthesis was observed at any level of $P_{i}$.

In terms of $P$ requirements of the rumen microbial population our results have shown a different requirement for cellulose digestion and for protein synthesis. For cellulose digestion, maximum activity appears to occur at $P_{i}$ concentrations between 5 and $25 \mathrm{mg} / 1$ but for protein synthesis no effect was observed until $P_{i}$ concentration fell below $5 \mathrm{mg} / 1$. However, Hungate (1966) suggested that mineral concentrations required for in vitro culture of bacterial cells may be appreciably less than those required in the rumen where more substrate is available for metabolism. It has been suggested that it is unlikely under practical conditions to produce $P$ deficiency in the rumen as far as microbes are concerned (Nel \& Moir, 1974) and generally on mixed diets, rumen $\mathrm{P}_{\mathrm{j}}$ concentrations are high (>200 mg/l) (Garton, 1951; Bennink et al. 1978). However, with all-roughage diets, even of reasonable quality, rumen $P_{i}$ concentrations can be below $50 \mathrm{mg} / \mathrm{l}$. Although salivary $P$ generally contributes over $60 \%$ of the soluble $P$ in the rumen (Wadsworth, 1977), and may balance short-term dietary $\mathbf{P}$ deficiencies, it must be borne in mind that the physical form and composition of the diet can markedly affect salivary output (Lawlor et al. 1966; Tomas, 1974; Wilson \& Tribe, $1963 a, b$ ) and dietary $\mathbf{P}$ would make a more substantial initial contribution to rumen $P_{i}$ concentrations. Thus, logically, dietary intake over prolonged periods would ultimately be the prime factor in determining $P_{i}$ concentrations in the rumen. Recommended intakes vary from $1 \cdot 6-7 \cdot 0 \mathrm{~g} / \mathrm{kg}$ DM but many tropical forages, poor-quality roughages and by-products contain considerably less than $1 \mathrm{~g} \mathrm{P} / \mathrm{kg} \mathrm{DM}$ (Smith, 1984; Komisarczuk, 1986) and not all of this will be available in the rumen.

Requirements for protein are generally estimated using the $\mathrm{N}: \mathrm{P}$ value of bacteria. In the present experiments, the mean N:P value of bacteria harvested from the control vessels was 6.50 in periods 2 and 3 . Taking a mean yield of microbial- $\mathrm{N}$ synthesized of $30 \mathrm{~g} \mathrm{~N} / \mathrm{kg}$ apparently fermented $\mathrm{OM}$ the $\mathrm{P}$ requirements can be expressed as $4.6 \mathrm{~g} \mathrm{P} / \mathrm{kg}$ apparently fermented OM. This is in the range of $4 \cdot 0-6.0$ found by other workers (Durand \& Kawashima, 1980; Durand et al. 1983b; Smith, 1984).

The authors thank Mr E. Schuller, Mr E. S. Griffiths and Miss P. E. Lewis for skilled technical assistance. This work was financed partly through the Agricultural and Food Research Council as part of a commission from the Ministry of Agriculture, Fisheries and Food and through CNRZ, France.

\section{REFERENCES}

Agricultural. Research Council (1980). The Nutrienı Requirements of Ruminant Livestock. Slough: Commonwealth Agricultural Bureaux.

Ammerman, C. B., Chicco, C. F., Masri, N. N., Moore, J. E. \& Shirley, R. L. (1965). Journal of Animal Science 24, 872 .

Anderson, R., Cheng, R. \& Burroughs, W. (1956). Journal of Animal Science 15, 489-495.

Barsdate, R. J., Prentki, R. T. \& Fenchel, T. (1974), Oikos 25, 239-251. 
Bass, J. M., Fishwick, G., Hemingway, R. G., Parkins, J. J. \& Ritchie, N. S. (1981). Journal of Agricultural Science, Cambridge 97, 365-372.

Bennink, M. R., Tyler, T. R., Ward, G. M. \& Johnson, D. E. (1978). Journal of Dairy Science 61, 315-323.

Bonilla, S. E. (1976). Phosphorus in the nutrition of sheep: composition of body fluids, microbial fermentation and feed intake. PhD Thesis, University of California, Davis.

Breves, G. \& Holler, H. (1983). In Protein Metabolism and Nutrition. vol. II, pp. $321-324$ [R. Pion, M. Arnal and D. Bonin, editors]. Paris: INRA.

Breves, G., Holler, H. \& Lessmann, H. W. (1985). Proceedings of the Nutrition Society 44, 145A.

Bryant, M. P., Robinson, I. M. \& Chu, H. (1959). Journal of Dairy Science 42, 1831-1847.

Burroughs, W., Latona, A., Depaul, P., Gerlaugh, P. \& Bethke, R. M. (1951). Journal of Animal Science 10, 693-705.

Caldwell, D. R., Kenney, M., Barton, J. S. \& Kelley, J. F. (1973). Journal of Bacteriology 114, 782-789.

Chapman, A. G. \& Atkinson, D. E. (1977). Advances in Microbial Physiology 15, 253-306.

Chicco, C. F., Ammerman, C. B., Moore, J. E., Van Walleghem, P. A., Arrington, L. R. \& Shirley, R. L. (1965). Journal of Animal Science 24, 355-363.

Coombe, J. B., Christian, K. R. \& Holgate, M. D. (1971). Journal of Agricultural Science, Cambridge 77, $159-174$.

Durand, M., Beaumatin, Ph., Dumay, C., Meschy, F. \& Komisarczuk, S. (1986). Reproduction, Nutrition, Développement 26, 297-298.

Durand, M., Beaumatin, Ph. \& Dumay, C. (1983a). Reproduction, Nutrition, Développement 23, 727-739.

Durand, M., Bertier, B., Hannequart, G. \& Gueguen, L. (1982). Reproduction, Nutrition, Développement 22 , 865-879.

Durand, M., Boxebeld, A., Dumay, C. \& Beaumatin, Ph. (1983b). In Protein Metabolism and Nutrition, vol II, pp. 263-266 [R. Pion, M. Arnal and D. Bonin, editors]. Paris: INRA.

Durand, M. \& Kawashima, R. (1980). In Digestive Physiology and Metabolism in Ruminants, pp. 375-408 [Y. Ruckebusch and P. Thivend, editors]. Lancaster: MTP Press Ltd.

Fishwick, G., Fraser, J., Hemingway, R. G., Parkins, J. J. \& Ritchie, N. S. (1977). Journal of Agricultural Science, Cambridge 88, 143-150.

Francis, G. L., Gawthorne, J. M. \& Storer, G. B. (1978). Applied and Environmental Microbiology 36, $643-649$.

Garton, G. A. (1951). Journal of Experimental Biology 28, 358-368.

Hall, D. G., Baxter, H. D. \& Hobbs, C. S. (1961). Journal of Animal Science 20, 817-819.

Hemingway, R. G. (1967). Outlook on Agriculture 5, 172-175.

Hoover, W. H., Crooker, B. A. \& Sniffen, C. J. (1976). Journal of Animal Science 43, 528-534.

Hungate, R. E. (1966). The Rumen and its Microbes. New York: Academic Press.

Komisarczuk, S. (1986). Etude de l'influence du phosphore sur l'activité fermentaire, la protéosynthèse et les teneurs en ATP de contenus de rumen dans différents systèmes de culture continu. PhD Thesis, Université de Paris-Sud.

Komisarczuk, S., Durand, M. \& Hannequart, G. (1984a). Reproduction, Nutrition, Développement $24,903$.

Komisarczuk, S., Merry, R. J. \& McAllan, A. B. (1985). Proceedings of the Nutrition Society 44, 141 A.

Komisarczuk, S., Merry, R. J. \& McAllan, A. B. (1986). Reproduction, Nutrition, Développement 26, $301-302$.

Komisarczuk, S., Merry, R. J., McAllan, A. B., Smith, R. H. \& Durand, M. (1984 b). Canadian Journal of Animal Science 64, Suppl., 35-36.

Latham, M. J., Sutton, J. D. \& Sharpe, M. E. (1974). Journal of Dairy Science 57, 803-810.

Lawlor, M. J., Giesecke, D. \& Walser-Karst, K. (1966). British Journal of Nutrition 20, 373-382.

Leedle, J. A. Z. \& Hespell, R. B. (1984). Journal of Dairy Science 67, 808-816.

McAllan, A. B. \& Smith, R. H. (1969). British Journal of Nutrition 23, 671-682.

McAllan, A. B. \& Smith, R. H. (1974). British Journal of Nutrition 31, 77-88.

McAllan, A. B. \& Smith, R. H. (1977). British Journal of Nutrition 37, 55-65.

McAllan, A. B. \& Smith, R. H. (1983). British Journal of Nutrition 50, 445-454.

McDougall, E. I. (1948). Biochemical Journal 43, 99-109.

Merry, R. J. \& McAllan, A. B. (1983). British Journal of Nutrition 50, 701-709.

Merry, R. J., Smith, R. H. \& McAllan, A. B. (1987). Archiv für Tierernährung (In the Press).

Milton, J. T. B \& Ternouth, J. H. (1984). Proceedings of the Australian Society of Animal Production 15, $472-475$.

Nel, J. W. \& Moir, R. J. (1974). South African Journal of Animal Science 4, 1-20.

Nuzback, D. E., Bartley, E. E., Dennis, S. M., Nagaraja, T. G., Galitzer, S. J. \& Dayton, A. D. (1983). Applied and Environmental Microbiology 46, 533-538.

Preston, R. L. \& Pfander, W. H. (1964). Journal of Nutrition 83, 369--378.

Smith, R. H. (1984). In Nuclear Techniques in Tropical Animal Diseases and Nutritional Disorders, pp. 79-96 [edited by International Atomic Energy Agency]. Vienna: IAEA.

Smith, R. H. \& McAllan, A. B. (1970). British Journal of Nutrition 24, 545-556.

Smith, R. H. \& McAllan, A. B. (1974). British Journal of Nutrition 31, 27-34.

Smith, R. H., McAllan, A. B., Hewitt, D. \& Lewis, P. E. (1978). Journal of Agricultural Science, Cambridge 90 , $557-568$.

Snedecor, G. W. \& Cochran, W. G. (1972). In Statistical Methods, 6th ed. Iowa State University Press. 
Stewart, C. S. (1975), Journal of General Microbiology 89, 319-326.

Sutton, J. D. (1979). Proceedings of the Nutrition Society 38, 275-281.

Tomas, F. M. (1974). Australian Journal of Agricultural Research 25, 485-493.

Van Nevel, C. J. \& Demeyer, D. I. (1977). British Journal of Nutrition 38, 101-114.

Wadsworth, J. C. (1977). Proceedings of the Nutrition Society of Australia 2, 89.

Wallace, R. J. \& West, A. A. (1982). Journal of Agricultural Science, Cambridge 98, 523-528.

Wilson, A. D. \& Tribe, D. E. (1963a). Australian Journal of Agricultural Research 14, 670-679.

Wilson, A. D. \& Tribe, D. E. (1963 b). Australian Journal of Agricultural Research 14, 680-689. 